\title{
Discourse Analysis of Teacher Talk: Code Switching in Content and Language Integrated Learning (CLIL) Classrooms in Thailand
}

\author{
Dorota Domalewska \\ War Studies University \\ Warsaw, Poland \\ Email: d.domalewska [AT] akademia.mil.pl
}

\begin{abstract}
This paper presents the results of a study on pedagogical functions of code switching in teacher discourse in Content and Language Integrated Learning (CLIL) classroom in a Thai university. The data was collected by means of structured classroom observation, field notes, and audio recordings. The findings suggest that code switching is used primarily for a preventive purpose; the explanation is given in L1 because otherwise the lesson would not be understandable for the students, mainly due to the students' low proficiency level. The instructor alternates languages in order to substitute words and phrases in another language and to emphasize content words and learning points that are the focus of the lesson. Self-repetition is the most frequently used emphasis technique. Furthermore, the lecturer code switches in order to give lucid clarification of difficult concepts and clear confusion, which facilitates learning.
\end{abstract}

Keywords - Content and Language Integrated Learning (CLIL), foreign language, code switching, Thai university

\section{INTRODUCTION}

Content and Language Integrated Learning (CLIL), i.e. teaching curricular content through a foreign language, most frequently English, has become commonplace in Thai schools. Bilingual programs are offered at various levels of education; at primary and secondary levels CLIL is most frequently introduced in the following subjects: math, science, health, computer science, and art, but usually around 50\% of the class time is devoted to the instruction given in L2 (Forman, 2005). The fundamental aims of these programs are to increase exposure to L2 and develop overall L2 competence as well as to improve academic achievement, increase cognitive flexibility, develop cross-cultural understanding, and prepare for internationalization. However, Lin and Man (2009: 15) maintain that in Thailand the aim of bilingual instruction is to develop communicative competence in L2 in addition to, not in replacement of, developing the dominant Thai language.

CLIL programs are not homogenous and depending on the amount of continued L1 and L2 use in the lesson the following models can by differentiated. First, lessons are delivered mainly in L2. The use of Thai is limited; it might be used merely to translate difficult concepts or wrap up the main points of the lesson. Second, code switching between Thai and English is frequent; however, English is the dominant language of the lesson. The mother tongue is used moderately mainly to explain difficult or fundamental concepts. Code switching takes place when the teacher believes it is necessary in order to meet the goals of the lesson at the same time developing high level of L2 competence. The characteristic of the third model is the use of the mother tongue as the language dominating the lesson. The teacher focuses on teaching the content of the subject rather than on the language of instruction. That is why, code switching is frequent with delivering the lesson content in L2 taking less than a half of lesson time. Finally, some bilingual schools favor the model of teaching when the lesson is delivered mainly in Thai but the students use textbooks and other resources in L2. The teacher presents the lesson in L1 because the students would otherwise have difficulties with understanding the subject's content. All in all, varying amounts of L2 used as the language of instruction may be implemented in different CLIL schools. That is why, overall achievement level in both the subject knowledge and L2 competence differs.

The question of how much of teacher talk in effective bilingual classrooms can be delivered in L1 proves to be crucial. Because patterns of language use enhance learning process, code switching in classroom discourse needs to be well considered in order to make teaching more effective. For this reason the present study sets out to analyze classroom discourse. More specifically, the research has been deigned to investigate to what extent code switching takes place and to analyze the reasons for code switching in teacher discourse. 


\section{CHALLENGE OF CLIL IMPLEMENTATION}

It is feared that teaching content through L2 may result in diminishing literacy skills in L1. At the tertiary level, it is argued that academic disciplines will not be available in the native language (Wilkinson, 2012). Furthermore, the quality of the teaching staff is questioned as teachers may lack disciplinary, teaching or language competence (Wilkinson, 2012).

Quality assurance is another concern as L2-medium instruction may lead to the impoverishment of the academic content (Dalton-Puffer, 2007); students might learn the academic content slower and not understand it completely so they fall behind their peers who learn the academic content in their L1. Inability to excel academically can undermine students' motivation (Dörnyei, 2001) and performance in class (Bozdoğan \& Buket, 2013). Undoubtedly, cognitive load differs depending on whether students learn the subject in L1 or L2. Teachers in bilingual programs analyze students' abilities required to achieve educational goals as well as their learning strategies as a result modifying their teaching approach to make it more effective for the particular group of students. For these reasons code switching is used so frequently in the lesson. It needs to be remembered that learning takes place when students are engaged in higher-order processing; the students will not learn the material if they are passive recipients in the lesson. Students are developing their higher-order processing if they are asked to analyze, synthesize and evaluate the learning material, connect it to their previously learned concepts and out-of classroom experience ( Rsida Himmele \& Himmele, 2009).

\section{EFFECT ON L2 PROFICIENCY AND ACADEMIC ACHIEVEMENT}

The body of research on CLIL indicate that teaching academic content through L2 considerably improves L2 learners' proficiency thanks to the communicative nature of the lessons and task-based learning (Dalton-Puffer, 2007). A large body of research (Gassner \& Maillat, 2006; Jimenez Catalan \& Ruiz de Zarobe, 2009; Puerto, Gallardo \& Gomez, 2009) shows beneficial effects of L2 medium instruction on different aspects of learning a language: lexis, syntax, pronunciation and overall communicative competence in L2. However, Airey (2010) points at the challenge of studying content through L2, especially discussing disciplinary concepts without using code switching. His study of university students in a physics course shows that although heavy at the beginning, the students' use of L1 reduces over time. Rollnick and Rutherford (1996) investigated science classrooms in Swaziland and found that students use their L1 to clarify concepts as well as to explore and formulate ideas that otherwise would remain unexposed whereas Bozdoğan and Buket (2013), who analyzed the performance in class of the students in Faculty of Science and Arts in Turkey, argue that teaching content through English decreases the students' participation in class and lowers their achievement. PayawalGabriel and Reyes-Otero (2006), who analyzed mathematics lessons, argue that the practice of using two languages alongside each other confused students; as a result, it is negatively correlated with their understanding.

Dalton-Puffer (2011) argues that students attending CLIL programs have the same amount of content knowledge as students who follow standard curricula. Furthermore, CLIL learners are more determined students who can cope with frustrating task better hence developing a higher degree of procedural competence in the subject. Whenever they face linguistic problems, those students do not drop the task but rather tend to do intensified mental construction activity (such as elaborating and relating details, finding contradictions). As a result, the students are engaged in deeper semantic processing and can understand the concepts they are studying (Vollmer et al., 2006 cited in Dalton-Puffer, 2011: 4). In comparison to students learning in their L1, CLIL students attain the same or even higher (especially among 10-14 year old learners) cognitional development (Jäppinen, 2005). Therefore, bilingual instruction promotes students' thinking and content learning.

\section{CODE SWITCHING}

The aim of bilingual education is to teach academic content in L2. However, teachers, both native and non-native speakers, frequently resort to L1 in the lesson. Code switching, i.e. the alternating use of two or more languages in a single conversation, is a natural conversational strategy in bilingual speech. Code-switching takes place either within the boundaries of a sentence (intra-sentential code switching) or between phrases (inter-sentential and tag code switching). Intra-sentential alternations can be referred to as code-mixing (Gardner-Chloros, 2009: 13); code-mixing frequently takes place unconsciously when the speaker fails to recall a term in one language.

Cook (2001) argues that language shifting in the classroom is a natural behavior. It is used in a bilingual classroom because it enhances learning as it allows greater comprehension of the studied material, plays the function of raising attention on the language point studied and is used when correction or explanation is necessary (Moore, 2002). Moreover, code alternation lowers affective barriers to L2 acquisition: it reduces anxiety and develops a sense of security. Baker (2011) lists the following functions of code switching: to emphasize a particular concept, to substitute an L2 word with an L1 alternative form, to express a notion that has no equivalent in L1, to reinforce a request, to clarify the message, to express identity and friendship, to ease tension and inject humor, change an attitude, and to introduce a topic into a conversation. Flyman-Mattson and Burenhult (1999), Greggio and Gil (2007) and Moore (2002) analyzed code switching of foreign language teachers and found out that both teachers and students resort to their mother tongue mainly for the following reasons: linguistic insecurity, topic switch (i.e. language alternates according to the topic that is discussed, e.g. grammar instruction or providing instructions), and repetitive function (i.e. monitoring or helping the 
students and giving explanation). Other reasons for code switching are affective function (i.e. expressing emotions) and socializing function (i.e. using L1 to express solidarity and friendship with the students).

An extensive body of research focused on the use of code switching in the foreign language classroom. Latsanyphone and Bouangeune (2009), who analyzed elementary English lessons in Lao, found that teaching vocabulary with L1 definitions and explanations improves the students' understanding and recollection of the studied lexis. Similarly, Ramachandran and Rahim (2004) studied the effectiveness of the translation method in teaching low proficiency level Malaysian students of English. They found that translating, which focuses on explicit learning of lexis, is positively correlated with the learners' recall and retention of vocabulary. Amorim (2012) argues that code switching holds a significant pragmatic function as it allows students to overcome communication breakdowns, perform longer turns as well as manage the task and other participants. Furthermore, students fall back on their L1 to fill in lexical or grammatical gaps in the foreign language in order to maintain the flow of communication. Similarly, Mujiono, Poedjosoedarmo, Subroto and Wiratno (2013) claim that code switching is a tactic that enables students reach communicative goals they would not be able to achieve otherwise due to their low levels of competence in L2. Moreover, code switching helps to increase learners' motivation. Liu, Ahn, Baek and Han (2004) reveal that students refer to their L1 when they are not capable of conveying message in L2 whereas teachers use L1 to clarify complex syntactic structures or lexical items. The study also shows that students tend to code switch to match the language used by the teacher. Other factors that determine switches to the native language include the topic's level of difficulty and learners' proficiency level.

The analysis of code-switching practices in the classroom triggered a large body of survey research that aim at investigating students' and teachers' perceptions on language alternation in the classroom. Amorim (2012), Jingxia (2010), and Nordin, Ali, Zubir and Sadjirin (2013) found that both teachers and students have a positive attitude towards code switching as it is a good strategy of efficiency that benefits the students, especially when L1 is used to explain difficult concepts (Ahmad \& Jusoff 2009). Furthermore, alternation between languages helps the learners feel more relaxed and boosts their confidence in learning a foreign language. In contrast, Cheng (2013) reports that teachers hold negative attitude towards code switching in class; however, they resort to L1 in order to explain grammar and abstract concepts believing it is beneficial for their learners.

\section{RESEARCH METHODOLOGY}

\subsection{Research Questions}

Taking into consideration the importance of high-quality teacher talk delivered in L2 and offering comprehensible input to learners, the question of how much of teacher talk in effective CLIL classrooms can be delivered in L1 proves to be crucial. There is a large body of research that provides insight into classroom discourse; however, the present study investigates patterns of language use in lecture mode teacher driven CLIL lessons. The following research questions were addressed in the study: (1) To what extent does code switching take place? (2) What are the functions of code switching in teacher discourse?

\subsection{Participants}

The present study draws on data collected in five 80-minute Applied Linguistics lessons in Rangsit University, Thailand. The number of students that attended the classes varied from 85 to 118 . English is a primary means of communication in class. The lessons were delivered in lecture mode by an experienced lecturer, a bilingual Thai-English speaker who holds an MA degree in the field of applied linguistics. The instructor was selected through the use of a purposive sampling. Both the lecturer and students signed consent forms having been given a brief description of the study but they were not informed about the exact purpose of the observations as the latter could have directly influenced the teacher-or student-talk in the classroom.

\subsection{Data Collection}

The data were collected by means of various methods: structured classroom observation, field notes, and audio recordings. The observer sat at the back of the class completing the observations schedule, making comprehensive field notes and audio recording the lessons. Altogether five 80-minute lectures were observed and recorded. The recorded materials have been transcribed and used for analysis. Structured observations allow to generate numerical data from the observations, which facilitates the analysis of patterns of classroom discourse (Punch, 2009). Observations were entered into an observation schedule that contained the following predetermined categories (Baker, 2011): emphasis of an important concept, substitution, i.e. an intrasentential switch when L1 phrase is replaced by an L2 equivalent, lack of equivalent in L1, reinforcement of a request, clarification of the message, expression of identity and friendship, off topic remarks not related to the topic of conversation, easing tension and injecting humor. 


\subsection{Data Analysis}

This research used both qualitative and quantitative analysis. The data analysis is based on the observation schedule completed during the lessons observation, field notes made during the observations and the transcription of the audio tapes. In order to perform quantitative analysis, observation schedule involved the predetermined categories. Every switch from Thai to English was noted and categorized. Only English switches in teacher discourse were analyzed.

The analysis was also qualitative in nature in order to explore in depth the pattern of code switching used in teacher discourse. The lessons were transcribed using discourse analysis as it allows in-depth analysis of patterns of code switching as well as links discourse with the broader social context in which it is used (Paltridge, 2012: 2).

\section{RESULTS}

Although English should be the primary medium of instruction in this bilingual classroom, the analysis revealed that the lectures were actually delivered in Thai with frequent switches to English. Code switching can serve various purposes: emphasis, substitution, lack of equivalent in L1, reinforcement of a request, clarification of the message, expression of identity and friendship, easing tension and injecting humor (Baker, 2011), and off topic comments. The analysis of audio data of the lecturer's discourse shows that the instructor's switches into English serve several functions. Figure 1 presents the frequency of each function of code switching.

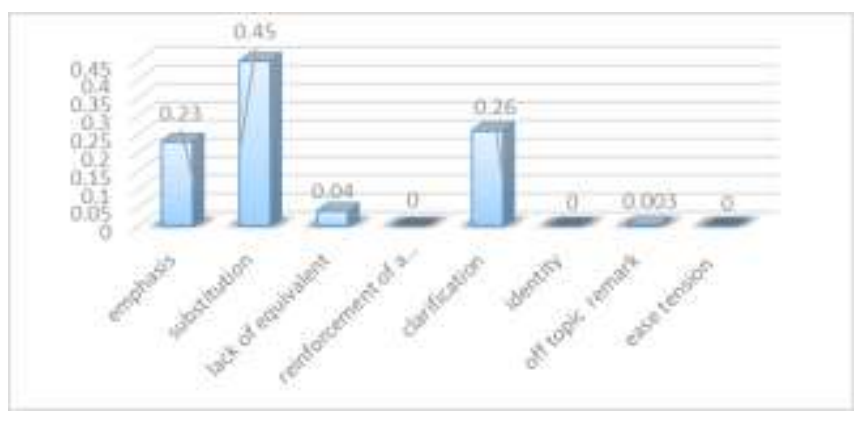

Figure 1. Frequency with which each function of code switching occurs

Code switching is used most commonly in order to substitute words and phrases in another language; it occurs both across sentence boundaries and intrasententially (code-mixing). The example below shows how the teacher combined L1 and L2 in order to substitute both a noun phrase and a sentence. L2 phrase occurs at sentence boundaries.

Example 1: ในประโยคทั้งประโยค ในประโยคทั้งประโยคเรียกว่า [The whole sentence is called] 1 construction. One construction consists of two constituents. One construction มี [has] two constituents.

Substitution also occurs intrasententially. The first example shows very frequent code mixing when every other phrase is expressed in a different language, but, like in the example above, English is the dominant language.

Example 2: Morpheme คือ [is] the smallest unit ของ [of] word นะ [polite particle; no meaning].

However, most frequently English words are inserted into a Thai sentence, as in the following example, which also shows that the instructor commonly refers to technical words, grammatical terms in English.

Example 3: จะไม่เรียกว่าประโยค ถ้าประโยคไม่มี verb. [A sentence must contain a verb].

The lecturer used two languages alongside each other to emphasize content words and learning points that are the focus of the lesson. The most frequent emphasis technique is self-repetition.

Example 4: อย่างนี้ถือว่าใช่ภาษาและวัฒนธรรม นะ นะ คือสัญลักษณ์เป็นวัฒนธรรมซึ่งไม่มีในสังคมไทยแน่ อันนี้ไม่มี อันนี้คือสัญลักษณ์ของหิมะหรือ snow ไม่มีนักศึกษาผมลงทุนให้เพื่อนบอกเอ้ย หยุด หยุด หยุด หยุด แล้วผมก็เอาแว่นขยายไปส่องเป็นแบบนี้จริงๆ เป็นแบบนี้จริงๆ หิมะ ถามว่าบ้านเรามีสัญลักษณ์แบบนี้ไหมไม่มี เพราะว่าเราไม่มีหิมะ [There are many symbols of language and culture. One such symbol, which is not present in Thailand, is snow or snow (English). Once I borrowed a magnifying glass from a friend to examine snow and it really glitters. It really does. We do not have such symbol because we don't have snow.]

The extracts quoted above show how the teacher uses L2 to emphasize the message expressed in L1. In a longer discourse presented in Thai the instructor inserts an English word in order to emphasize the key word in the message. However, more frequently the instructor repeats a code switched utterance. The technique is used to emphasize subject content; the instructor either repeats a previously code switched phrase in the same sentence (73\% of the repeated phrases) or in another sentence (a quarter of the repetitions). It is interesting to note that the teacher does not change the 
form of the phrase but modifies stress or intonation in order to make the phrase stand out, which can be observed in the following examples:

Example 5: ทุกภาษาจะต้องเป็น duality ซึ่ง duality ก็คือ sounds and meaning duality เป็นเรื่องของ sounds and meaning เป็น 2 อย่างที่อยู่ในเวลาเดี่ยวกันนะครับและ duality จะเป็นนามธรรมนะครับ เป็น sounds กับ meaning. [Duality (English) is a characteristic of every language (Thai). Duality (English) refers to (Thai) sounds and meaning duality (English); it refers to (Thai) sounds and meaning (English) that are present at the same time (Thai). Duality (English) is an abstract concept. It is (Thai) sounds (English) and (Thai) meaning (English)]

In the example above the instructor repeats the phrase 'duality' as well as 'sounds and meaning' in order to point out the language required to learn the content of the lesson and emphasize key points of the material. Thus, the teacher enhances comprehension and makes the difficult concepts more clear, as in the following example:

Example 6: The term of เสียง คือ sound s-o-u-n-d แต่ไม่ใช่ noise ซึ่ง noise คือเสียงซึ่งมันอึกทึก เค้าเรียก noise แต่ถ้าเป็น sound จะหมายถึงเสียงที่เปล่งออกมา เสียงที่เปล่งออกมาใน ในระหว่างที่มนุษย์ communication. [The term (English) sound means (Thai) sound s-o-u-n$\mathrm{d}$ (English), which is distinct from (Thai) noise (English) which (Thai) noise (English) is deafening sound that is called (Thai) noise (English) but the term (Thai) sound (English) refers to the emitted sound. It is the articulated sound used by people in (Thai) communication (English)]

The aim of self-repetition is to clarify concepts, mark a distinction between ambiguous concepts 'sound' and 'noise', which in Thai language may be expressed with the same lexical item 'เสียง'. Furthermore, the teacher highlights the spelling of the word, which is a common technique used by the instructor.

Example 7: ลักษณะร่วมที่ 2 คือ length l-e-n-g-t-h length คือความยาวของเสียง length คือการที่เสียงเปล่งออกมาได้นานเท่ากับเสียงหนึ่ง [The second shared feature is (Thai) length l-e-n-g-t-h length (English), that is the sound length (Thai) length (English), which is as long as the voiced sound (Thai)]

The examples presented above show repetition of a phrase within a sentence. However, the technique is also used when the concept is repeated in another sentence:

Example 8: มันเกิดการรวมเสียงเพราะเสียงหนึ่งคือเสียง ด ส ตอนนี้มาดู tone เป็นสิ่งที่เกดขึ้นในภาษาแล้วก็ makes the difference in sound sorry makes the difference in meaning ใน environment. ในภาษาไทย tone in Thai ในภาษาไทยมี tone อยู่ 5 ภาษา เครื่องหมายกำกับ tone เรียกว่า tone mark. [It was a sound that does not exhibit a change in quality because it is a single sound ' $k$ ', 's'; for example (Thai) tone (English) makes a difference in a language (Thai) makes the difference in sound sorry makes the difference in meaning (English) in the (Thai) environment (English). In Thai language (Thai) tone in Thai (English) In Thai language there are (Thai) tone (English). There are 5 (Thai) tone (English) marks called (Thai) tone mark (English)]

In the extract presented above the teacher repeats the English word 'tone'; however, the use of repetition is not only confined to L2 utterances as Thai phrases are also repeated, such as ‘ในภาษาไทย' (in Thai language) in the example quoted above. These repetitions do not add any new information to the subject matter but they help facilitate comprehension.

The data presented above indicate that the aim of self-repetition serves multiple functions: highlighting important information, enhancing comprehension, facilitating retention, and modelling pronunciation. Both Thai and English phrases are repeated; the repetition is reduced to a short phrase without changing the original form of the message.

The instructor frequently code switches in order to give lucid clarification of difficult concepts the students are supposed to master. The two languages are mixed so that the students grasp complex concepts; the explanation is most frequently given in L1 with key words being presented or translated into English. Using code switching for clarification through examples can be broadly divided into two types. First, the teacher provides various examples of English words to illustrate various linguistic phenomena as in the following extracts:

Example 9: Prefix and suffix มีผลต่อไวยกรณ์นะครับ เช่นคำว่า happy เปลี่ยน $\mathrm{y}$ เป็น $\mathrm{i}$ แล้วเติม ness จาก adjective จะกลายเป็น noun เป็น happiness. Happy เป็น happiness นะ [Prefix and suffix (English) affect grammatical category; for example in the word (Thai) happy (English) 'y' changes to 'i' then (Thai) ness (English) is added to form (Thai) a noun 'happiness' (English) from (Thai) an adjective (English). Happy (English) is (Thai) happiness (English) (polite particle in Thai)]

The extract quoted above demonstrates how the teacher elucidates complex linguistic concepts (word formation) through examples provided in English thus making the lesson more accessible to the learners. The teacher frequently compares L1 and L2 to identify structural differences between the two linguistic codes, which helps to develop the students' language analytic ability.

Unlike the previous extracts when the explanation provided in L1 was enriched with examples of English words used to illustrate various linguistic phenomena, the following sample demonstrates that the explanation of a theory is carried using alternating languages. 
Example 10: เป็น 1 พยางค์ เพราะมีสระอีและเป็น 1 คำเพราะมันมีความหมายในตัวมัน แต่ถ้าพูดคำว่า มะม่วง มี two syllables แต่เป็น one word สาเหตุที่เป็น two syllables มะ and ม่วง แต่มะม่วงหรือ mango. [It is one syllable because there is one vowel ' $\mathrm{e}$ ' and it is one word because it is meaningful. But when we say the word 'mango' there are (Thai) two syllables (English) but it is (Thai) one word (English) because (Thai) two syllables (English) 'man' (Thai) and (English) 'go' (Thai) form one word mango or (Thai) mango (English)]

The aim of code switching in the above examples is to elucidate complex linguistic phenomena that the students would not understand if the explanation was provided in L2. Thus, it may be assumed that the instructor alternates between languages in a preventing purpose as he expects the learners will find linguistic theories difficult to understand. For this reason, translation is used extensively in teacher talk as in the following example:

Example 11: ในเสียง เสียงในภาษาอังกฤษ can be divided into two. One is segmental, segmental คือเสียงสระ พยัญชนะ วรรณยุกต vowels, consonants and tones. [Sounds, English sounds (Thai) can be divided into two. One is segmental, segmental (English), which is related to vowels, consonants and tones (Thai) vowels, consonants and tones (English)]

Another reason for using English is related to the fact that numerous loanwords in Thai language are derived from English. In the process of encoding loanwords it was difficult to determine whether the word is a borrowing or a switch. A number of English words permeate Thai vocabulary; however, if a Thai word exists and is frequently used to refer to the phenomenon, it was not considered a loanword (e.g. adjective, semantic, diphthong). Data analysis reveals the use of many lexical borrowings: Christmas, Santa Clause, YouTube, OK, freshy, freshy night, TOEFL, Halloween, mail, email, CD, adidas, Nike, thumb drive, subtitle. The loanwords are interwoven in Thai discourse as in the following example:

Example 12: โดยโหลดรายงานลง YouTube แล้วส่ง mail. [By uploading to (Thai) YouTube (English) and sending by (Thai) mail (English)]

The examples presented above prove that English borrowings have become integrated into everyday Thai vocabulary and are conventionally used as part of Thai language. Filling lexical gaps leads to borrowing words related to technology (e.g. YouTube, CD, e-mail), culturally specific lexis (e.g. Christmas, Santa Clause, freshy) or proper names (e.g. Adidas, Nike, TOEFL). In the process of borrowing words frequently undergo morphological, phonological, orthographic or syntactic adaptation. Hence, in the examples quoted above the lexical borrowings are pronounced with Thai accent. Other loanwords have undergone morphological adaptation.

Finally, code switching is used for off-topic remarks. These English words or phrases are inserted into a Thai discourse but are not on the main topic, see the following examples:

Example 13: จากเสียงที่ไม่สั่นกลายเป็นเสียงสั่น นี่คือธรรมชาติและวัฒนธรรมของภาษาญี่ปุ่น all right มะ [A long sound turned into a short sound, which is a cultural feature of Japanese language (Thai) all right (English) (polite particle in Thai).

As can be seen from the examples above, the off-topic remarks are a part of Thai discourse. They are irrelevant to the discussion and are used to express affirmation.

Data analysis does not reveal the use of English for other purposes, i.e. reinforcement of a request, identity, easing tension. Thai language may be used to perform these functions, but it is beyond the scope of this study to analyze Thai discourse.

\section{DISCUSSION AND CONCLUSIONS}

The purpose of this paper is to investigate the reasons for code switching in the CLIL lesson and to analyze the type of code switching in teacher discourse. The results show that the instructor alternates languages in order to clear confusion, improve comprehension, facilitate retention, and emphasize technical terms and concepts related to the lesson content. These findings relate to those of Flyman-Mattsson and Burenhult (1999) who argue that code switching is frequently used to explain difficult concepts and repeat the previously uttered sentences whereas Moghadam, Samad and Shahraki (2012) and Mujiono, Poedjosoedarmo, Subroto and Wiratno (2013) found the use of code switching to check understanding, clarify misunderstandings, translate, socialize and make it easier to convey the message. Thus, it may be concluded that the instructor code switches for a preventive purpose; the explanation is given in L1 because otherwise the lesson would not be understandable for the students, especially due to the students' low proficiency level.

Finally, the analysis revealed frequent use of translation and explanation of English words in Thai, which is used to convey meaning and explain unfamiliar concepts. It is short and effective as it does not interrupt the flow of the lesson. Thus, it is used as a learning tool of pedagogical value to emphasize recently taught concepts and make input more comprehensible to ensure successful learning. Finally, due to its systematic use, translation and explanation through L1 helps to achieve the goals of the lesson. This technique is most frequently employed to clear misunderstanding and ambiguity. The teacher also uses translation to emphasize new concepts and highlight significant information. Thus, the present findings confirm that, as other researchers have reported (Jingxia, 2010; Latsanyphone \& Bouangeune, 2009; 
Moghadam, Samad \& Shahraki, 2012; Ramachandran \& Rahim, 2004), L1 is employed to translate difficult concepts, which facilitates comprehension and positively correlates with the learners' recall and retention of vocabulary.

The use of mother tongue by the teacher can be justified by several reasons (Atkinson, 1993). First, the students have a low level of language proficiency whereas the lessons involve complex content (topics related to linguistics) delivered in a lecture mode. Teaching complex concepts requires clarity of communication to increase understanding and reduce ambiguity. Furthermore, the students are used to lessons taking place mainly in their L1; therefore, they may expect a great deal of teaching to be carried out in Thai. Students naturally incorporate their new knowledge to the already existing native-language schemata. Hence, L1 is a resource they draw their existing knowledge and a strategy to lighten cognitive load. Therefore, the present study lends further support to previous studies revealing that code switching is frequently employed in teacher discourse to cater for the needs of the students. The amount of code switching is determined by the students' low level of proficiency in L2, which is in line with other studies (Atkinson, 1997; Carless, 2004; Jingxia, 2010) as well as the complexity of content (topics related to linguistics) delivered in a lecture mode and students' expectations (Atkinson, 1997).

In the light of the research analysis, code switching can be seen as a useful tool used to clear misunderstandings, facilitate communication and reduce ambiguity. However, in order to enhance learning, students need to be exposed to rich L2 input; thus, the use of the target language needs to be maximized, especially in bilingual instruction where English should be the primary means of communication. Code-switching may only be used to meet valid pedagogical purposes. Future research is needed to identify best practices that improve the quality of learning opportunities for Thai students.

\section{REFERENCES}

[1] Ahmad Badrul Hisham, Jusoff Kamaruzaman, "Teachers' code-switching in classroom instructions for low English proficient learners", English Language Teaching, vol. 2, no. 2, 2009.

[2] Airey John, "The ability of students to explain science concepts in two languages", Hermes-Journal of Language and Communication Studies, vol. 45, pp. 35-49, 2010.

[3] Amorim Rita, "Code switching in student-student interaction; functions and reasons!", Revista de Estudos Linguísticos da Univerdade do Porto, pp. 177-195, 2012.

[4] Atkinson David, Teaching Monolingual Classes, London: Longman, 1993.

[5] Baker Colin, Foundations of Bilingual Education and Bilingualism, Multilingual Matters, 2011.

[6] Bozdoğan Derya, Buket Karlidag, "Neglected Productive Skills in Content-based Classes", Procedia-Social and Behavioral Sciences, vol. 70, pp. 1152-1162, 2013.

[7] Catalán Rosa Maria Jimenez, De Zarobe Yolanda Ruiz, "The receptive vocabulary of EFL learners in two instructional contexts: CLIL versus non-CLIL instruction”, Content and language integrated learning: Evidence from research in Europe, pp. 81-92, 2009.

[8] Carless David Robert, "A contextualised examination of target language use in the primary school foreign language classroom”, EIE Journal Publications, 2004.

[9] Cheng Xiaoli, "Research on Chinese College English Teachers' Classroom Code-switching: Beliefs and Attitudes", Journal of Language Teaching and Research, vol. 4, no. 6, pp. 1277-1284, 2013.

[10] Cook Vivian, "Using the first language in the classroom", Canadian Modern Language Review/La Revue canadienne des langues vivantes, vol. 57, no. 3, pp. 402-423, 2001.

[11]Dalton-Puffer Christiane, Discourse in Content and Language Integrated Learning (CLIL) Classrooms. John Benjamins Publishing, 2007.

[12] Dalton-Puffer Christiane, "Content-and-language integrated learning: From practice to principles?", Annual Review of applied linguistics, vol. 31, pp. 182-204, 2011.

[13] Del Puerto F. Gallardo, Gomez Esther, "Testing the effectiveness of content and language integrated learning in foreign language contexts: The assessment of English pronunciation", in de Zarobe Yolanda Ruiz, Cataln Rosa Mar-A Jim'nez (eds.) Content and Language Integrated Learning: Evidence from Research in Europe, Multilingual Matters, 2009.

[14] Dörnyei Zoltan, "New themes and approaches in second language motivation research", Annual Review of Applied Linguistics, vol. 21, pp. 43-59, 2001.

[15]Forman Ross, Teaching EFL in Thailand: A bilingual study, Doctoral dissertation, University of Technology, Sydney, 2005.

[16] Flyman-Mattsson Anna, Burenhult Niclas, "Code-switching in second language teaching of French", Lund Working Papers in Linguistics, vol. 47, pp. 59-72, 2009.

[17] Gardner-Chloros Penelope, Code-switching, Cambridge University Press, 2009.

[18] Gassner Denise, Maillat Didier, "Spoken competence in CLIL: a pragmatic take o-n recent Swiss Data", Current Research on CLIL, vol. 15, 2006.

[19] Greggio Saionara, Gil Gloria, “Teacher's and learner's use of code-switching in the English as a foreign language classroom: a qualitative study”, Linguagem \& Ensino, vol. 10, no. 2, pp. 371-393, 2007. 
[20]Rsida Himmele P., Himmele William, The language-rich classroom: A research-based framework for teaching English language learners. ASCD, 2009.

[21] Jäppinen Aini-Kristina, "Thinking and content learning of mathematics and science as cognitional development in content and language integrated learning (CLIL): Teaching through a foreign language in Finland", Language and Education, vol. 19, no. 2, pp. 147-168, 2005.

[22] Jingxia Liu, "Teachers' code-switching to the L1 in EFL classroom”, The Open Applied Linguistics Journal, vol. 3, pp. 10-23, 2010.

[23] Latsanyphone Soulignavong, Bouangeune Souvannasy, "Using L1 in teaching vocabulary to low English proficiency level students: A case study at the National University of Laos”, English Language Teaching, vol. 2, no. 3, pp. 186-193, 2009.

[24]Lin, Angel, Man Evelyn Y., Bilingual education: Southeast Asian perspectives, Hong Kong University Press, 2009.

[25]Liu Dilin, et al. "South Korean high school English teachers' code switching: Questions and challenges in the drive for maximal use of English in teaching", Tesol Quarterly, vol. 38, no. 4, pp. 605-638, 2004.

[26] Moghadam Soodeh Hamzehlou, Samad Adlina Abdul, Shahraki Elham Rahmani, "Code Switching as a Medium of Instruction in an EFL Classroom", Theory and Practice in Language Studies, vol. 2, no. 11, pp. 2219-2225, 2012.

[27] Moore Daniele, "Code-switching and learning in the classroom”, International Journal of Bilingual Education and Bilingualism, vol. 5, no. 5, pp. 279-293, 2002.

[28] Mujiono Poedjosoedarmo, Soepomo Subroto Edi, Wiratno Tri, "Code Switching in English as Foreign Language Instruction Practiced by the English Lecturers at Universities”, International Journal of Linguistics, vol. 5, no. 2, pp. 46-65, 2013.

[29] Nordin Noli Maishara et al. "ESL Learners Reactions Towards Code Switching in Classroom Settings", Procedia-Social and Behavioral Sciences, vol. 90, pp. 478-487, 2013.

[30] Paltridge Brian, Discourse Analysis: An Introduction. Bloomsbury Publishing, 2012.

[31] Payawal-Gabriel J., Reyes-Otero M. "Comprehensible input strategies and pedagogical moves using Filipino/English as medium of instruction in secondary Mathematics”, Education Quarterly, pp. 83-97, 2006.

[32] Punch Keith F. Introduction to Research Methods in Education. Sage, 2009.

[33] Ramachandran Sharimllah, Devi Rahim, Hajar Abdul, "Meaning recall and retention: The impact of the translation method on elementary level learners' vocabulary learning," RELC Journal, vol. 35, no. 2, pp. 161178,2004

[34] Rollnick Marissa, Rutherford Margaret. "The use of mother tongue and English in the learning and expression of science concepts: a classroom-based study", International Journal of Science Education, vol. 18, no. 1, pp. 91-103, 1996.

[35] Wilkinson Robert, "English-medium instruction at a Dutch university: Challenges and pitfalls", Englishmedium instruction at universities: Global challenges, pp. 3-24, 2013. 